\title{
HUBUNGAN PENGETAHUAN DAN SIKAP IBU NIFAS TENTANG ASI KOLOSTRUM DENGAN PEMBERIAN ASI KOLOSTRUM PADA BAYI BARU LAHIR
}

\author{
Fitriyani Pulungan \\ Jurusan Kebidanan Politeknik Kesehatan Kemenkes Medan \\ Email :fitriyanipulungan@gmail.com
}

\begin{abstract}
WHO recommends mothers to exclusively breastfeed their babies in the first 6 months after birth to achieve optimal growth, development and health. This study aims to determine the relationship between knowledge and attitudes of postpartum mothers with colostrum breastfeeding for newborns in the working area of the Rambung Public Health Center, South Binjai District in 2017. The design of this study used an analytic survey, with a cross sectional approach. The sampling was purposive sampling with a total sample of 86 people in the working area of the Rambung Health Center, Rambung Dalam Village, South Binjai District, North Sumatra Province. The data used are secondary and primary. Data were analyzed by chi-square test. The results of the study, there was a significant relationship between the attitude of postpartum mothers with colostrum breastfeeding in the working area of the Rambung Health Center, Rambung Dalam Village, South Binjai District, North Sumatra Province with $p$ value $=0.000<(0.05)$. Giving colostrum breast milk to newborns because it can help provide comfort and strengthen baby antibodies early, so it is hoped that the Rambung Health Center, especially health workers, can improve service programs, especially counseling and socialization to postpartum mothers that the importance of colostrum breastfeeding for newborns.
\end{abstract}

Keywords: Knowledge, Attitude, and Giving Colostrum

\begin{abstract}
ABSTRAK
WHO merekomendasikan pada ibu di seluruh dunia untuk menyusui secara eksklusif pada bayinya dalam 6 bulan pertama setelah lahir untuk mencapai pertumbuhan yang optimal, perkembangan dan kesehatan. Penelitian ini bertujuan mengetahui hubungan pengetahuan dan sikap ibu nifas dengan pemberian ASI kolostrum pada bayi baru lahir di wilayah kerja puskesmas rambung kecamatan binjai selatan tahun 2017. Desain penelitian ini menggunakan survey analitik, dengan pendekatan cross sectional. Pencuplikan sampel purposive sampling dengan jumlah sampel 86 orang di wilayah kerja Puskesmas Rambung Kelurahan Rambung Dalam Kecamatan Binjai Selatan Provinsi Sumatera Utara. Data yang digunakan adalah sekunder dan primer. Data dianalisis uji chi-square. Hasil penelitian, ada hubungan yang signifikan antara sikap ibu nifas dengan pemberian ASI kolostrum di wilayah kerja Puskesmas Rambung Kelurahan Rambung Dalam Kecamatan BinjaiSelatan Provinsi Sumatera Utara dengan nilai $p$ value $=0,000<\alpha(0,05)$. Pemberian ASI kolostrum pada bayi baru lahir karena dapat membantu memberikan kenyamanan dan memperkuat antibodi bayi secara dini, sehingga diharapkan pihak Puskesmas Rambung khususnya tenaga kesehatan agar dapat meningkatkan program pelayanan khususnya penyuluhan dan sosialisasi kepada ibu nifas bahwa pentingnya pemberian ASI kolostrum pada bayi baru lahir.
\end{abstract}

Kata kunci : Pengetahuan, Sikap, dan Pemberian Kolostrum 


\section{PENDAHULUAN}

Data WHO (World Health Organization) tahun 2000 Angka Kematian Bayi (AKB) di dunia 54 per 1000 kelahiran hidup, sedangkan Angka Kematian Bayi yang cukup tinggi di dunia pada tahun 2012 yaitu sebesar 35 per 1000 kelahiran hidup (1). Rendahnya tingkat pemberian colostrum menjadi salah satu pemicu status gizi bayi dan balita di Indonesia rendah ${ }^{(2)}$. WHO merekomendasikan pada ibu di seluruh dunia untuk menyusui secara eksklusif pada bayinya dalam 6 bulan pertama setelah lahir untuk mencapai pertumbuhan yang optimal, perkembangan dan kesehatan ${ }^{(2)}$. WHO (World Health Organization) menyebutkan angka kejadian gizi buruk pada balita di Indonesia tahun 2002 meningkat 8,3\% dan gizi kurang 27\%. Tahun 2007 tercatat sebanyak empat juta balita Indonesiamengalami gizi kurang dan 700 ribu anak dalam kategori gizi buruk. 2 Sebanyak 3 juta anak di antaranya meninggal tiap tahun akibat gizi kurang ${ }^{(1)}$.

Tolak ukur dan indikator suatu negara dalam menentukan tingkat kesehatan masyarakatnya salah satunya adalah Angka Kematian Bayi (AKB). Di Indonesia pada tahun 2012 menurut SDKI (Survei Demografi dan Kesehatan Indonesia) tercatat Angka Kematian Bayi masih sangat tinggi yaitu 32 kematian per 1000 kelahiran hidup, itu artinya dalam satu tahun sekitar 125.000 bayimeninggal sebelum mencapai usia satu tahun dan Angka Kematian Neonatal (AKN) kisaran 20/1.000 kelahiran hidup. Target MPS (Making Pregnancy Safer) yaitu strategi untuk meningkatkan kesehatan ibu dan bayi baru lahir pada tahun 2010 menurunkan AKN menjadi 16/1000 kelahiran hidup dan menurunkan AKB menjadi kurang dari 32 per 1000 kelahiran hidup pada tahun 2015 (Depkes RI), yang diikuti dengan adanya target review status MDGs (Millenium Development Goals) target MDGs tahun 2015 terhadap penurunan AKB menjadi 28/1000 kelahiran hidup, yang belum tercapai sehingga penggantinya makadiluncurkan suatu sistem baru yang bernama SDGs (Sustainable Depelopment Goals ${ }^{(3)}$.

Menurut SDKI tahun 2012 pemberianASI kepada bayi satu jam paska persalinan sebesar 49,3\%, sedangkan pemberian ASI kepada bayi pada hari pertama setelah kelahirannya adalah $66,25 \%$. Hal ini masih belum sesuai dengan harapan program pemerintah. Pentingnya pemberian ASI kolostrum tidak diimbangi oleh perilaku ibudalam pemberian ASI kolostrum pada bayi Pemberian ASI kolostrum mengalami peningkatan pada tahun 2011 yaitu berdasarkan Profil Data Kesehatan Indonesia tahun 2011 pemberian ASI kolostrum di Indonesia yaitu $61,5 \%$, dan di Sumatera Utara 56,6\% ${ }^{(4)}$.

Berdasarkan Rikesdas (2010), diperoleh bahwa persentase perilaku ibu di Indonesia yang membuang kolostrum baik sebagian maupun seluruhnya adalah sebesar25,3\%. Untuk wilayah Sumatera Utara didapati angka yang lebih tinggi yaitu sebesar $28,2 \%$ (5).

Masalah yang sering dijumpai kebiasaan yang salah yang dilakukan ibuIndonesia dalam menyusui bayinya yaitu memberikan cairan ASI yang sudah berwarna putih dan cairan yang kental berwarna kuning atau colostrum dibuang karena dianggap menyebabkan sakit perut, oleh karena itu sebelum susu matur (ASI) keluar, bayi diberi makanan pengganti seperti air gula dan madu, akibat dari kurangnya pemahaman tersebut maka merugikan kesehatan bayi itu sendiri ${ }^{(6)}$.

Air susu ibu (ASI) merupakan makanan bayi yang paling penting terutama pada bulan-bulan pertama kehidupan. ASImerupakan sumber gizi yang sangat ideal dengan komposisi yang seimbang dan sesuai dengan kebutuhan pertumbuhan bayi.Komposisi ASI itu sendiri tidak sama dari waktu ke waktu komposisi tersebut terbagi atas tiga macam yaitu kolostrum, ASI masa transisi dan ASI matur $^{(6)}$

Kolostrum atau jolong berasal dari bahasa latin "colostrum" adalah jenis susu yang dihasilkan oleh kelenjar susu dalam tahapakhir kehamilan dan beberapa hari setelah kelahiran bayi. Kolostrum manusia warnanya kekuningan dan kental. Kolostrum penting bagi bayi mamalia (termasuk manusia) karena mengandung banyak gizi dan zat-zat pertahanan tubuh. Kolostrum ( $\mathrm{IgG}$ ) mengandung banyak karbohidrat, protein, antibodi dan sedikit lemak (yang sulit dicerna bayi). Bayi memiliki sistem pencernaan kecil, dan kolostrum memberinya gizi dalam konsentrasi tinggi. Kolostrum juga mengandung zat yang mempermudah bayi buang air besar pertama kali yang disebut meconium. Hal ini membersihkannya daribilirubin, yaitu sel darah merah yang mati yang diproduksi ketika kelahiran ${ }^{(7)}$.

Pada penelitian Mery (2009) di klinik Bersalin Martini Kecamatan Medan Tembung yaitu perilaku ibu dalam pemberian ASI kolostrum masih tergolong cukup yaituperilaku baik hanya $29,9 \%$. Hal tersebut masihsangat jauh dari harapan bila dibandingkan dengan manfaat ASI kolostrum itu sendiri. Dan diikuti dengan hasil penelitian Eni (2011) tentang Hubungan tingkat pengetahuan ibu menyusui dengan pemberian ASI pertama (kolostrum) di Rumah 
Bersalin An-Nissa Surakarta, menyatakan bahwa terdapat hubungan yang bermakna antara tingkat pengetahuan ibu dengan pemberian ASI pertama atau kolostrum, dengan hasil ujistatistik menunjukkan p-value $=0,000^{(8)}$.

Berdasarkan data rekapitulasi laporan gizi puskesmas rambung tahun 2016 bahwa target cakupan asi eksklusif sebesar $65 \%$, namun yang tercapai hanya sebesar $41,5 \%$. Hasil survey awal data yang diperoleh pada bulan Des-Feb 2017 jumlah ibu nifas diPuskesmas Rambung ibu yang melahirkan berjumlah 92 orang. Dari hasil survei dan wawancara dengan ibu postpartum diperoleh data ada sebagian ibu post partum yang tidak memberikan kolostrum pada bayi karena sebagian dari mereka melahirkan di rumah sakit,yang mana masih banyak rumah sakit yang belum menerapkan IMD sehingga ibu tidak bisa memberikan kolostrum pada bayinya.

Berdasarkan latar belakang di atas, maka peneliti ingin melakukan penelitian yangberjudul: “ Hubungan Pengetahuan dan Sikap Ibu Nifas dengan Pemberian Asi Kolostrum Pada Bayi Baru Lahir di Wilayah Kerja Puskesmas Rambung Kecamatan Binjai Selatan.

\section{Tujuan Penelitian (Opsional)}

Mengetahui Hubungan Pengetahuan Dan Sikap Ibu Nifas Dengan Pemberian ASI Kolostrum Pada Bayi Baru Lahir di Wilayah KerjaPuskesmas Rambung Kecamatan Binjai Selatan.

\section{Hipotesis (Opsional)}

Ada Hubungan Pengetahuan Dan Sikap Ibu Nifas Tentang Asi Kolostrum Dengan Pemberian ASI Kolostrum Pada BayiBaru Lahir

\section{METODE}

Jenis penelitian adalah kuantitatif dengan desain survey analitik. Jumlah populasi dalam penelitian ini adalah sebanyak 110 orang dengan rumus Slovin dengan tinggkat kepercayaan $95 \%$ diperoleh sampel 86 orang. Dengan kriteria inklusi berdomesili di wilayah kerja Puskesmas Rambung, ibu nifas yang melahirkan bayi dalam keadaan hidup, ibu nifas yang memberikan ASI kolostrum kepada bayinya, ibu nifas yang baru melahirkan 0-4 hari. Informed consent dan etichal clearance didapatkan sebelum pelaksanaan penelitian. Analisis data dengan uji statistik uji chi-square $(\alpha=0,05)$.

\section{HASIL}

Tabel 1. Distribusi Frekuensi Pengetahuan ibu Dengan Pemberian ASI Kolostrum Di Wilayah Kerja Puskesmas Rambung

\begin{tabular}{lll}
\hline Pengetahuan & Frekuensi & $\begin{array}{l}\text { Presentase } \\
(\boldsymbol{\%})\end{array}$ \\
\hline Kurang & 27 & 31,4 \\
Cukup & 49 & 57,0 \\
Baik & 10 & 11,6 \\
Total & 86 & 100 \\
\hline
\end{tabular}

Berdasarkan table 1 diketahui bahwa dari 86 responden menunjukkan bahwa mayoritas pengetahuan responden terhadap pemberian ASI Kolostrum memiliki pengetahuan cukup yaitu sebanyak 49 orang $(57,0 \%)$.

Tabel 2. Distribusi Frekuensi Sikap Ibu Dengan Pemberian ASI Kolostrum Di Wilayah Kerja Puskesmas Rambung Kecamatan Binjai Selatan

\begin{tabular}{ccc}
\hline Sikap & Frekuensi & Persentasi \\
& & $(\boldsymbol{\%})$ \\
\hline Kurang & 75 & 87,2 \\
Baik & 11 & 12,8 \\
Total & 86 & 100 \\
\hline
\end{tabular}

Berdasarkan tabel 2 diketahui bahwa dari 86 responden menunjukkan bahwa mayoritas sikap responden terhadap pemberian ASI Kolostrum memiliki sikap kurang yaitu sebanyak 75 orang $(87,2 \%)$

Tabel 3. Distribusi Frekuensi Pemberian ASIKolosrtum Pada Bayi Baru Lahir di Wilayah Kerja Puskesmas Rambung Kecamatan BinjaiSelatan

\begin{tabular}{ccc}
\hline $\begin{array}{c}\text { Pemberian ASI } \\
\text { Kolesterum }\end{array}$ & $\begin{array}{c}\text { Frekuen } \\
\text { si }\end{array}$ & $\begin{array}{c}\text { Presen } \\
\text { tasi }\end{array}$ \\
\hline Diberikan & 11 & 12,8 \\
Tidak diberikan & 75 & 87,2 \\
Total & 86 & 100 \\
\hline
\end{tabular}

Berdasarkan tabel 4.3. diatas diketahui bahwa dari 86 responden menunjukkan bahwa mayoritas pemberian ASI Kolostrum tidak diberikan yaitu sebanyak 75 orang $(87,2 \%)$.

Tabel 4. Tabulasi Silang Antara Pengetahuan Dengan Pemberian ASI Kolostrum Pada Bayi Baru Lahir Di Wilayah Kerja Puskesmas Rambung Kecamatan Binjai Selatan

\begin{tabular}{|c|c|c|c|c|c|}
\hline \multirow[t]{3}{*}{$\begin{array}{l}\text { Penget } \\
\text { ahuan }\end{array}$} & \multicolumn{2}{|c|}{$\begin{array}{l}\text { Pemberian } \\
\text { Kolesterum }\end{array}$} & \multirow{2}{*}{\multicolumn{2}{|c|}{ Total }} & $\begin{array}{l}\text { Va } \\
\text { lue }\end{array}$ \\
\hline & $\begin{array}{c}\text { Tidak } \\
\text { Diberikan }\end{array}$ & $\begin{array}{l}\text { Diberi } \\
\text { kan }\end{array}$ & & & \\
\hline & $\mathbf{N} \quad \%$ & $\mathbf{N} \quad \%$ & $\mathbf{N}$ & $\%$ & \\
\hline
\end{tabular}



Vol. 16 No. 3 September - Desember 2021

\begin{tabular}{lcccccll} 
Kurang & 27 & 100 & 0 & 0 & 27 & 10 & 0,0 \\
Cukup & 48 & 98 & 1 & 2 & 49 & $\begin{array}{l}10 \\
00\end{array}$ \\
& & & & & & 0 & \\
Baik & 0 & 0 & 10 & 10 & 10 & 10 & \\
& & & & 0 & & 0 & \\
\hline Total & 75 & 87,2 & 11 & 12 & 86 & 10 & \\
& & & &, 8 & & 0 & \\
\hline
\end{tabular}

Berdasarkan tabel 4.4. menunjukkandari 86 responden yang diteliti bahwa yangberpengetahuan kurang sebanyak 27 orang $(100 \%)$ dan keseluruhan tidak memberikan kolostrum, sebaliknya yang berpengetahuan baik sebanyak 10 orang $(100 \%)$ dan keseluruhan memberikan kolostrum.

Uji statistik Chi-Square diperoleh nilai $p$ value $=0,000<\alpha(0,05)$ maka hipotesa $H_{a}$ diterima - Artinya terdapat hubungan yang signifikan antara pengetahuan ibu nifas dengan pemberian ASI kolostrum pada bayi baru lahir.

Tabel 5. Tabulasi Silang Antara Sikap Dengan Pemberian ASI Kolostrum Pada Bayi Baru Lahir Di Wilayah Kerja Puskesmas Rambung Kecamatan Binjai Selatan

\begin{tabular}{|c|c|c|c|c|c|c|c|}
\hline \multirow{2}{*}{$\begin{array}{c}\text { Sik } \\
\text { ap }\end{array}$} & \multicolumn{4}{|c|}{ Pemberian Kolesterum } & \multicolumn{2}{|c|}{ Total } & \multirow{2}{*}{$\begin{array}{l}\text { V } \\
\mathbf{a} \\
\mathbf{l} \\
\mathrm{u} \\
\mathrm{e}\end{array}$} \\
\hline & $\begin{array}{r}T \\
\text { Dib }\end{array}$ & $\begin{array}{l}\text { ak } \\
\text { ikan }\end{array}$ & Di & ikan & & & \\
\hline & $\mathbf{N}$ & $\%$ & $\mathbf{N}$ & $\%$ & $\mathbf{N}$ & $\%$ & \\
\hline $\begin{array}{l}\text { Kur } \\
\text { ang }\end{array}$ & 75 & $\begin{array}{l}10 \\
0\end{array}$ & 0 & 0 & 75 & $\begin{array}{l}10 \\
0\end{array}$ & 0 \\
\hline $\begin{array}{l}\text { Bai } \\
k\end{array}$ & 0 & 0 & 11 & $\begin{array}{l}10 \\
0\end{array}$ & 11 & $\begin{array}{l}10 \\
0\end{array}$ & \\
\hline $\begin{array}{l}\text { Tot } \\
\text { al }\end{array}$ & 75 & $\begin{array}{l}87 \\
, 2\end{array}$ & 11 & $\begin{array}{l}12, \\
8\end{array}$ & 86 & $\begin{array}{l}10 \\
0\end{array}$ & \\
\hline
\end{tabular}

Berdasarkan tabel 4.5. menunjukkan dari 86 responden yang di teliti bahwa yang memiliki sikap kurang sebanyak 75 orang $(100 \%)$ dan keseluruhan tidak memberikan kolostrum, sebaliknya yang memiliki sikap baik sebanyak 11 orang $(100 \%)$ dan keseluruhan memberikan kolostrum.

Uji statistik Chi-Square diperoleh nilaip value $=0,000<\alpha(0,05)$ maka hipotesa $H_{a}$ diterima . Artinya terdapat hubungan yang signifikan antara sikap ibu nifas denganpemberian ASI kolostrum pada bayi baru lahir.

\section{PEMBAHASAN}

Distribusi Frekuensi Pengetahuan Ibu Nifas Dengan Pemberian ASI Kolostrum Di Wilayah

\section{Kerja Puskesmas Rambung Kecamatan Binjai Selatan}

Menurut Notoatmodjo (2010), pengetahuan itu sendiri dipengaruhi olehfaktor pendidikan formal ${ }^{(9)}$. Pengetahuan sangat erat hubungannya dengan pendidikan, dimana diharapkan bahwa dengan pendidikan yang tinggi maka orang tersebut akan semakin luas pula pengetahuannya, sehingga seseorang semakin besar keinginan untuk memanfaatkan pengetahuan dan keterampilan dan pendidikan seseorang berperan dalam membentuk sikap dan perilaku seseorang dalam berinteraksi dengan lingkungan. Karena hasil pendidikan ikut membentuk pola pikir, pola persepsi dan sikap pengambilan keputusan seseorang.

Hal ini dapat dipengaruhi oleh beberapafaktor yang mempengaruhi pengetahuan seseorang yaitu tingkat pendidikan, informasi, dimana seseorang yang mempunyai sumber informasi banyak akan memberikan pengetahuan yang lebih jelas, kultur budaya, sangat berpengaruh terhadap tingkat pengetahuan seseorang karena informasi yang baru akan disaring sesuai dengan budaya dan agama yang dianut, pengalaman, dimana berkaitan dengan umur yang bertambah danpendidikan yang lebih baik akan memudahkan dalam menyerap informasi yang diberikan serta bersikap lebih bijak, sosial ekonomi, tingkatan pendapatan seseorang untuk memenuhi kebutuhan hidup, mitos, merupakan kepercayaan yang dipunyai oleh seseorang, dan biasanya terjadi pada daerah tertentu dan agama yang dianut, pengalaman, dimana berkaitan dengan umur yang bertambah danpendidikan yang lebih baik akan memudahkan dalam menyerap informasi yang diberikan serta bersikap lebih bijak, sosial ekonomi, tingkatan pendapatan seseorang untuk memenuhi kebutuhan hidup, mitos, merupakan kepercayaan yang dipunyai oleh seseorang, dan biasanya terjadi pada daerah tertentu dan dijadikan kebiasaan, nilai agama, dimana kemampuan berpikir abstrak remaja memungkinkannya untuk dapatmentransformasikan keyakinan beragamanya (9). Harapan dengan pengetahuan yang meningkat atau baik pada ibu post partum tentang kolostrum, akan berpengaruh pada sikap dan praktik dapat berubah dengan keinginan untuk memberikan kolostrum pada bayinya.

Penelitian ini tidak sejalan dengan hasil penelitian Esi dan Erniyati (2012), yang berjudul pemberian kolostrum pada suku karo di desa sukanalu kecamatan barusjahe kabupaten karo menunjukkan bahwa mayoritasresponden memiliki pengetahuan baik sebanyak 30 orang $(51,7 \%)$, yang mana semakin baik pengetahuan maka semakin baik juga perkembangan seorang ibu nifas terhadap informasi khususnya tentang pemberian ASI kolostrum pada bayi baru lahir ${ }^{(10)}$. 
Penelitian ini sejalan dengan hasil penelitian Dame dan Gustien (2014), yang berjudul hubungan pengetahuan dan sikap ibu nifas dengan pemberian ASI kolostrum pada bayi baru lahir di Wilayah Kerja Puskesmas Putri Ayu Kota Jambi menunjukkan bahwa mayoritas responden yang memiliki pengetahuan kurang baik $(75,0 \%)$. Pendidikan ibu yang rendah memungkinkan seorang ibu kurang dalam mengadopsipengetahuan yang baru dan akan menghambat perkembangan sikap seorang ibu terhadap informasi khususnya tentang pemberian ASI kolostrum pada bayi baru lahir ${ }^{(11)}$

Penelitian ini tidak sejalan dengan hasil penelitian Eni Sulastri (2010), yang

berjudul hubungan tingkat pengetahuantentang asi dengan pemberian kolostrum pada ibu menyusui di Kecamatan Kerjo Kabupaten Karanganyar menunjukkan bahwa mayoritas responden yang memiliki pengetahuan baik 59orang $(47,6 \%)^{(8)}$.

Menurut asumsi peneliti, sebaiknya agar pengetahuan ibu baik diharapkan kepada petugas kesehatan agar memberikan penyuluhan maupun konseling kepada ibu nifas.

\section{Distribusi Frekuensi Sikap Ibu NifasDengan Pemberian ASI Kolostrum Di Wilayah Kerja Puskesmas Rambung Kecamatan Binjai Selatan}

Sikap merupakan reaksi atau respon yang masih tertutup dari seseorang terhadap stimulus atau obyek sehingga suatu sikap belum tentu akan diwujudkan dalam bentuk suatu tindakan. Faktor-faktor lain termasuk faktor pendukung seperti fasilitas yang ada juga diperlukan untuk mengubah sikap menjadi tindakan yang positif. Sikap tidak dibawa sejak lahir, tetapi dipelajari dan dibentuk berdasarkan pengalaman dan latihan sepanjang perkembangan individu.Sebagai makhluk sosial, manusia tidak lepas daripengaruh interaksi dengan orang lain, selain makhluk individual. Kedua faktor tersebut berpengaruh terhadap sikap ${ }^{(12)}$.

Penelitian ini tidak sejalan dengan hasil penelitian Esi dan Erniyati (2012), yang berjudul pemberian kolostrum pada suku karo di desa sukanalu kecamatan barusjahe kabupaten karo menunjukkan bahwa mayoritasresponden memiliki sikap positif sebanyak 48 orang $(82,8 \%)$ Diharapkan dengan ibu yangsudah bersikap positif terhadap pemberian kolostrum ditambah dengan dukungan dari lingkungan maka akan mempermudah terbentuknya perilaku pemberian kolostrum yang baik ${ }^{(10)}$.

Penelitian ini sejalan dengan hasil penelitian Dame dan Gustien (2014), yang berjudul hubungan pengetahuan dan sikap ibu nifas dengan pemberian ASI kolostrum pada bayi baru lahir di Wilayah Kerja Puskesmas Putri Ayu Kota Jambi menunjukkan bahwa mayoritas responden yang memiliki sikap negatif $(59,4 \%)$ sikap ibu yang negatif terhadap pemberian kolostrum dikarenakan kurangnya dukungan dari keluarga dan masyarakat (11)

Dalam hal pemberian kolostrum faktordari ibu pengaruhnya sangat kuat. Hasil penelitian UNICEF (2003) mengatakan dibeberapa Negara Asia Tenggara, ada praktik- praktik tradisional yang tidak mendukungpemberian kolostrum..Juga terjadi beberapa praktik saat / segera setelah dilahirkan atau pada masa neonatal terbukti merugikan kesehatan bayi baru lahir. Praktik praktik tersebut akan merugikan atau menghilangkan keuntungan pemberian kolostrum Bila mitos ini dijalankan akan banyak sekali kolostrumyang bagus terbuang sia-sia. Penelitian ini dilakukan di daerah pedesaan sehingga dimungkinkan budaya tersebut di atas, masih ada yang mempraktikkannya.

Menurut asumsi peneliti, pada dasarnya cara untuk memperbaiki sikap juga sama seperti dengan mengubah pengetahuanyaitu memberikan penyuluhan maupun konseling kepada ibu nifas. Diharapkan dengan metode ini, peningkatan pemberian ASI Kolostrum dapat tercapai.

\section{Hubungan Pengetahuan Ibu Nifas Dengan Pemberian ASI Kolostrum Di Wilayah Kerja Puskesmas Rambung Kecamatan Binjai Selatan}

Berdasarkan hasil analisis bivariatdidapat hasil uji statistik Chi-Square nilai pvalue adalah 0,000 berarti nilai $\mathrm{p}$ Value $<0,05$ menunjukkan adanya hubungan yang signifikan antara pengetahuan ibu nifas dengan pemberian ASI kolostrum pada bayi baru lahir. Penelitian ini sejalan dengan penelitian Maryati (2008) menunjukan bahwa terdapat hubungan tingkat pengetahuantentang kolostrum dengan perilaku pemberiankolostrum dengan nilai $\mathrm{p}$ value $0,339<$ 0,05 di

Puskesmas Nglipar Gunung Kidul ${ }^{(13)}$.

Penelitian ini sejalan dengan hasilpenelitian Esi dan Erniyati (2012), menunjukkan terdapat hubungan yang bermakna antara pengetahuan responden dengan Pemberian Kolostrum dengan nilai $\mathrm{p}$ value $0,000<0,05$ di Desa Sukanalu Kecamatan Barusjahe Kabupaten Karo ${ }^{(10)}$.

Penelitian ini sejalan dengan penelitian Situngkir dan Gustien (2014) menunjukan bahwa terdapat hubungan tingkat pengetahuan responden dengan pemberian ASIkolostrum pada bayi baru lahir di Wilayah Kerja Puskesmas Putri Ayu Kota Jambi Tahun2014 dengan nilai p value $0,014<0,05$ (11).

Penelitian ini sejalan dengan penelitian Eni Sulastri (2010), menunjukan bahwa terdapat 
hubungan antara tingkat pengetahuan tentang ASI dengan pemberian kolostrum di kecamatan Kerjo kabupaten Karanganyar dengan p value $=0,000<$ $0,05^{(8)}$.

Penelitian ini tidak sejalan dengan penelitian Yuliana, dkk (2013), menunjukanbahwa tidak terdapat hubungan antara tingkat pengetahuan tentang ASI dengan pemberian kolostrum di wilayah kerja Puskesmas Bonto Cani Kabupaten Bone dengan p value $=1,132$ $>0,05^{(14)}$.

Secara teoritis diketahui bahwa pengetahuan mempunyai kontribusi yang besar dalam mengubah perilaku seseorang untuk berbuat sesuatu. Selain itu, pengetahuan ibu sangat erat kaitannya terhadap pemberian kolostrum karena dapat membantu dalam meningkatkan sistem imun bayi baru lahir.

Dalam hal ini, pengetahuan tentang kolostrum tidak boleh dikesampingkan tetapi justru harus diberikan/ditingkatkan kepada ibu-ibu menyusui. Selain itu sangat perlu adanya pendampingan pada ibu setelahmelahirkan untuk segera menyusui bayinya meskipun ASI belum keluar. ASI yang keluar dalam hari pertama (kolostrum) banyak mengandung zat anti yang diperlukan oleh bayi untuk pertahanan terhadap berbagai penyakit.

Menurut asumsi peneliti, agar pemberian ASI Kolostrum dapat teraplikasikan secara maksimal di masyarakat khususnya bagi ibu nifas dan pendamping persalinan sebaiknya adanya peningkatan sosialisasi sertakonseling yang berisi pendidikan kesehatan tentang pentingnya kolostrum dari petugas kesehatan secara menyeluruh di wilayah kerja Puskesmas Rambung Kecamatan Binjai Selatan agar pengetahuan ibu lebih baik dan mereka lebih paham secara signifikan akan pentingnya pemberian kolostrum.

\section{Hubungan Sikap Ibu Nifas Dengan Pemberian ASI Kolostrum Di Wilayah Kerja Puskesmas Rambung Kecamatan Binjai Selatan}

Berdasarkan hasil analisis bivariat didapat hasil uji statistik Chi-Square nilai $p$ value adalah 0,000 berarti nilai $p$ Value $<0,05$ menunjukkan adanya hubungan yang signifikanantara sikap ibu nifas denganpemberian ASI kolostrum pada bayi baru lahir.Penelitian ini sejalandengan penelitian Sintia (2013), menunjukkan bahwa bahwa ada hubungan bermakna antara sikapdengan pemberian ASI Kolostrum paada bayi baru lahir dengan p-value $=$ $0,03<0,05^{(15)}$.

Hasil penelitian menunjukkan terdapat hubungan yang bermakna antara sikap ibu terhadap pemberian kolostrum dengan nilai p value $0,000<$
0,05 di di Desa Sukanalu Kecamatan Barusjahe Kabupaten Karo.

Penelitian ini sejalan dengan penelitian Situngkir dan Gustien (2014)menunjukan bahwa terdapat hubungan sikap responden dengan pemberian ASI kolostrum pada bayi baru lahir di Wilayah Kerja Puskesmas Putri Ayu Kota Jambi Tahun 2014dengan nilai p value $0,041<0,05^{(11)}$.

Penelitian ini tidak sejalan dengan penelitian Yuliana, dkk (2013), menunjukanbahwa tidak terdapat hubungan antara sikap responden tentang ASI dengan pemberian kolostrum di wilayah kerja Puskesmas Bonto Cani Kabupaten Bone dengan $\mathrm{p}$ value $=0,154$

$>0,05^{(14)}$.

Sikap merupakan reaksi atau respon yang masih tertutup dari seseorang terhadapstimulus atau obyek sehingga suatu sikap belum tentu akan diwujudkan dalam bentuksuatu tindakan. Faktorfaktor lain termasuk faktor pendukung seperti fasilitas yang ada juga diperlukan untuk mengubah sikap menjadi tindakan yang positif. Sikap tidak dibawa sejak lahir, tetapi dipelajari dan dibentuk berdasarkan pengalaman dan latihan sepanjang perkembangan individu. Sebagai makhluk sosial, manusia tidak lepas daripengaruh interaksi dengan orang lain, selain makhluk individual. Kedua faktor tersebut berpengaruh terhadap sikap ${ }^{(12)}$.

Dalam hal pemberian kolostrum faktor dari ibu pengaruhnya sangat kuat. Hasil penelitian UNICEF (2003) mengatakan di beberapa Negara Asia Tenggara, ada praktik- praktik tradisional yang tidak mendukung pemberian kolostrum. Juga terjadi beberapa praktik saat / segera setelah dilahirkan atau pada masa neonatal terbukti merugikan kesehatan bayi baru lahir. Praktik - praktik tersebut akan merugikan atau menghilangkan keuntungan pemberian kolostrum Bila mitosini dijalankan akan banyak sekali kolostrumyang bagus terbuang sia-sia. Penelitian ini dilakukan di daerah pedesaan sehingga dimungkinkan budaya tersebut di atas, masih ada yang mempraktikkannya.

Pada kenyataanya, walaupun ibu-ibu menyusui bayi mereka, namun pengaruh kebiasaan yang kurang menunjang pemanfaatan kolostrum secara optimal seperti pemberian makanan tambahan pada bayi baru lahir dan pemberian minuman pengganti kolostrum, dengan alasan kolostrum belum keluar. Terdapat juga ibu-ibu yang belum mengerti tentang cara pemberian dan kapan waktu yang tepat memberikan makan pendamping ASI. Banyak ibu beranggapan bahwa bayi yang menangis setelah diberikan kolostrum, menandakan bahwa bayi masih lapar dan kolostrum saja tidak cukup. Hal ini didorong juga oleh budaya dari keluarga terdahulu, yang memberikan makanan seperti pisang pada bayi baru lahir agar bayi berhenti menangis. 
Menurut asumsi peneliti, hal ini disebabkan karena kurangnya dukungan tenaga esehatan dalam memberikan pendidikan kesehatan kepada ibu nifas yang mana sebagian dari mereka melakukan persalinan di rumah sakit, di mana masih ada rumah sakit yang belum menerapkan IMD sehingga ibu nifas tidak bisa memberikan kolostrum kepada bayinya, dan di samping itu peran bidan dapat bekerja sama dengan tokoh yang pengaruhnya lebih besar dalam mendukung ibu nifas untuk mengubah pola pikirnya seperti kader, dukun, atau praktikpraktik tradisional, suami bahkan keluarga dalam memberikan penyuluhan dan pelatihan seputar pentingnya pemberian ASI kolostrum, sehingga diharapkan pemberian ASI kolostrum dapat teraplikasikan dengan baik di masyarakat.

\section{KESIMPULAN}

Ada hubungan yang bermakna antara antara pengetahuan ibu nifas dengan pemberian ASI kolostrum dan sikap ibu nifas dengan pemberian ASI kolostrum pada bayi baru lahir di wilayah kerja puskesmas Rambung kecamatan Binjai selatan dengan analisa data menggunakan Chi-Squared nilai $p$ value $=0,000<\alpha(0,05)$.

\section{DAFTAR PUSTAKA}

1. Sariana. Angka Kematian Bayi dan Kejadian Gizi Buruk Menurut MDGs. 2015; Available from: http://lp3msht.files.wordpress.com

2. Kodrat L. Dasyatnya ASI \& Laktasi. Yogyakarta: Mesia Baca; 2010.

3. Depkes RI. Menerjemahkan Tujuan Pembangunan Berkelanjutan (MDGs) dalam Agenda Pembangunan Nasional. 2015; Available from: www.depkes.go.id/articel/view/1509290000 3/menerjemahkan-tujuan-pembangunanberkelanjutan-sdg-s-dalam-agendapembangunan-nasional.html

4. Kemenkes RI. Profil Kesehatan Indonesia. 2012;

5. Apriani EF. Faktor-Faktor Ibu Menyusui dalam Pemberian Kolostrum pada BBL di Polonia Kecamatan Medan Polonia. 2015;

6. Sukari, Nensy Ratnawati dkk. Gambaran Pengetahuan Ibu Post Partum tentang kolostrum di puskesmas Bahu Manado. 2014; Available from: http://ejurnal.unsrat.ac.id/index.php/jkp/articl e/view/5254/4767

7. Proverawati A\& ER. Kapita Selekta ASI \& Menyusui. Yogyakarta: Nuha Medika; 2010.

8. Sulastri E. Hubungan Tingkat Pengetahuan Tentang ASI dengan Pemberian Kolostrum Pada Ibu Menyusui di Kecamatan Kerjo Kabupaten Karanganyer. 2010;
9. Notoatmodjo S. Metodologi Penelitian Kesehatan. Jakarta: Rineka Cipta; 2010.

10. Tarigan EP dan E. Pemberian Kolostrum Pada Suku Karo di Desa Sukanalu Kecamatan Barusjahe Kabupaten Karo. 2012; Available from:

http://jurnal.usu.ac.id/index.php/jkt/article/vi ew/309

11. Situngkir D dan G. Hubungan Pengetahuan dan Sikap Ibu Nifas Dengan Pemberian ASI Kolostrum Pada Bayi Baru Lahir Di Wilayah Kerja Puskesmas Putri Ayu Kota Jambi Tahun 2014. 2014;

12. Maulana M. Promosi Kesehatan. Jakarta: Salemba Medika; 2009.

13. Maryati E. Hubungan Tingkat Pengetahuan Ibu Menyusui dengan Pemberian ASI Pertama (Kolostrum) di Rumah Bersalin AnNissa Surakarta. 2008;

14. Yulianah dkk. Hubungan Antara Pengatahuan, Sikap dan Kepercayaan Ibu Dengan Pemberian ASI Eksklusif di Wilayah Kerja Puskesmas Bonto Cani Kabupaten Bone Tahun 2013. 2013; Available from: http://repository.unhas.ac.id/bitstream/handle /123456789/5560/JURNAL.pdf

15. Sintia. Penelitian Analitik desain Potong Lintang Pada Bulan Desember 2012- Januari 2013. 2013;

name of publisher; 2018. 20-29 p. 